\title{
Quantitative Assessments of U.S. Safeguards on Steel Products
}

\author{
Hiro Lee ${ }^{\mathrm{a}, *}$ \\ Research Institute for Economics and Business Administration \\ Kobe University, Kobe 657-8501, Japan \\ Dominique van der Mensbrugghe \\ The World Bank, Washington, DC 20433, USA
}

July 2004

\begin{abstract}
In March 2002, the United States imposed temporary safeguard measures on 11 steel products in the forms of higher tariffs and tariff-rate quotas. Using a dynamic computable general equilibrium (CGE) model, we evaluate the effects of U.S. safeguards on economic welfare, real GDP, steel trade, and sectoral output and average cost of the United States and its trading partners, with particular attention to those of Japan, China, Korea and Taiwan. The results suggest that the U.S. welfare marginally increased during the two years when the safeguards were in effect because of an improvement in the terms of trade. By contrast, the safeguards had a small negative impact on U.S. real GDP. Japan, Korea and Taiwan incurred some welfare losses, but they were extremely small. China did not suffer any welfare losses. U.S. steel imports from the Northeast Asian countries declined by 9-25 percent, but those from the NAFTA partners and other countries on the exclusion list increased by 10-11 percent, largely offsetting the reductions in the total U.S. steel imports. The safeguards caused output contraction in the steel-consuming industries in the United States and output expansion in those industries in Japan, Korea and Taiwan, but these effects were again extremely small. These results suggest that the impact of U.S. safeguards was minimal.
\end{abstract}

JEL classification: F13; F14

Keywords: Safeguards, steel, CGE model

\footnotetext{
a Corresponding author. E-mail: hlee@rieb.kobe-u.ac.jp; tel.: +81-78-803-7023; fax: +81-78-803-7059.

* We would like to thank William E. James, Oleksandr Movshuk, and particularly Eric D. Ramstetter for helpful comments on an earlier version. We are solely responsible for any errors that remain.
} 


\section{Introduction}

In the last three and a half decades, the U.S. steel industry has been protected by a variety of import relief measures, including voluntary restraint agreements (VRAs), the trigger price mechanism (TPM), and antidumping and countervailing duties. The imposition of safeguard measures in March 2002 on 11 steel product categories in the forms of higher tariffs and tariff-rate quotas (TRQs) ${ }^{1}$ was the latest of a series of U.S. protection of its steel industry and escalated the efforts of the U.S. government to restrict steel imports. ${ }^{2}$ The safeguards were not imposed on the NAFTA trading partners (Canada and Mexico), nor the great majority of developing countries. Some of the developing countries that were not exempted included China, Korea and Brazil, which are major steel producers in the world. ${ }^{3}$ The U.S. government intended to impose the safeguard measures for a period of three years, but in May 2003 the World Trade Organization (WTO) dispute panel ruled that these measures were in violation of WTO rules and in November 2003 the WTO Appellate Body upheld the major findings of the panel ruling. ${ }^{4}$ In December 2003 the United States decided to terminate the safeguard measures.

The recent U.S. protection policy might have temporarily reduced its steel imports from the Northeast Asian countries, the European Union (EU) and other non-exempt countries. At the same time, the U.S. action has harmed its automobile, heavy equipment, construction and other steel-consuming industries by raising the cost of intermediate input (e.g., Francois and Baughman, 2001; USITC, 2003). Hufbauer and Goodrich (2003) estimate that the safeguards increased the average domestic steel price in the United States

\footnotetext{
${ }^{1}$ In the tariff-rate quota scheme, a given tariff rate is applied to imports up to a specified quantity (i.e., the quota), and then a higher tariff rate is applied to imports over the quota.

2 Detailed information on Section 201 of the Trade Act of 1974 (Global Safeguard Investigations) is available at the U.S. International Trade Commission (USITC) website (http://www.usitc.gov/us201. htm).

${ }^{3}$ While safeguards are imposed only on slabs and flat products for Brazil, theses are Brazil's major exported steel products.

4 The countries/regions that challenged the U.S. measures to the WTO were the European Union (EU), China, Japan, Korea, Switzerland, Norway, New Zealand and Brazil. Claims made by the complainants are provided in World Trade Organization (2003).
} 
by 3.3 percent. Francois and Baughman (2001) suggest that the provision of import relief remedies for steel would impose cost of \$1.9-4.0 billion a year on consumers and reduce U.S. national income by $\$ 500$ million to $\$ 1.4$ billion a year. U.S. steel producers would gain \$242-496 million, but these gains would not re-establish the U.S. steel industry to be profitable. USITC (2003) estimates that the effect of the safeguards using a static singlecountry computable general equilibrium (CGE) model and finds that the aggregate effect ranges from a welfare gain of $\$ 65.6$ million to a welfare loss of $\$ 110.0$ million, with a central estimate of a welfare loss of \$41.6 million. It also estimates that the capital income of the steel industry would increase by $\$ 240$ million (3.03 percent) and that of the steelconsuming industries would decrease by $\$ 601$ million (0.01 percent).

Using a dynamic multi-country CGE model, we evaluate the effects of U.S. safeguards on economic welfare, real GDP, steel trade, sectoral output and unit cost of the United States and its trading partners, with particular attention to those of Japan, China, Korea and Taiwan, over the period 2002-2005. Unlike the model used by USITC (2003) that can only evaluate the aggregate and sectoral effects within the United States, our model can assess the effects on U.S. trading partners. In addition, by using a dynamic model, we can more accurately specify the safeguard duties that are different between the first and second year. The next section provides the trends in U.S. steel imports by trading partners during the 1970-2001 period. An overview of the model is given in section 3, followed by a brief description of the scenario in section 4. Assessments of general equilibrium effects of the U.S. safeguards are provided in section 5. The final section summarizes the main findings of this paper.

\section{Trends in U.S. Steel Imports by Trading Partners, 1970-2001}

Figure 1 provides the trends in the shares of U.S. steel imports from selected trading partners over the period 1970-2001. Several noticeable trends are readily observable from this figure. First, the share of U.S. steel imports from Japan declined drastically from about 50 percent in 1976 to under 10 percent in 2000-2001. The decline in the Japanese share over the 1976-92 period were largely attributable to two factors: (1) the introduction of TPM from 1978-82, where minimum reference prices for imported steel 
were instituted, ${ }^{5}$ and (2) VRAs were in effect from 1984-1992. Second, the share of imports from the EU also declined significantly - from 45 percent in 1971 to 26 percent in 2001. Third, although Korea's steel exports to the United States increased rapidly during the 1970-83 period, its exports to the U.S. relative to other trading partners showed a slight downward trend during 1983-1997 before recovering in 1998-2001. Fourth, China, now the world's largest steel producer in tonnage, started to export its steel to the United States in the mid-1980s, but the share has remained relatively small (1-4 percent in 1990-2001).

Figure 1: Shares of U.S. Steel Imports by Trading Partners, 1970-2001 (percent)
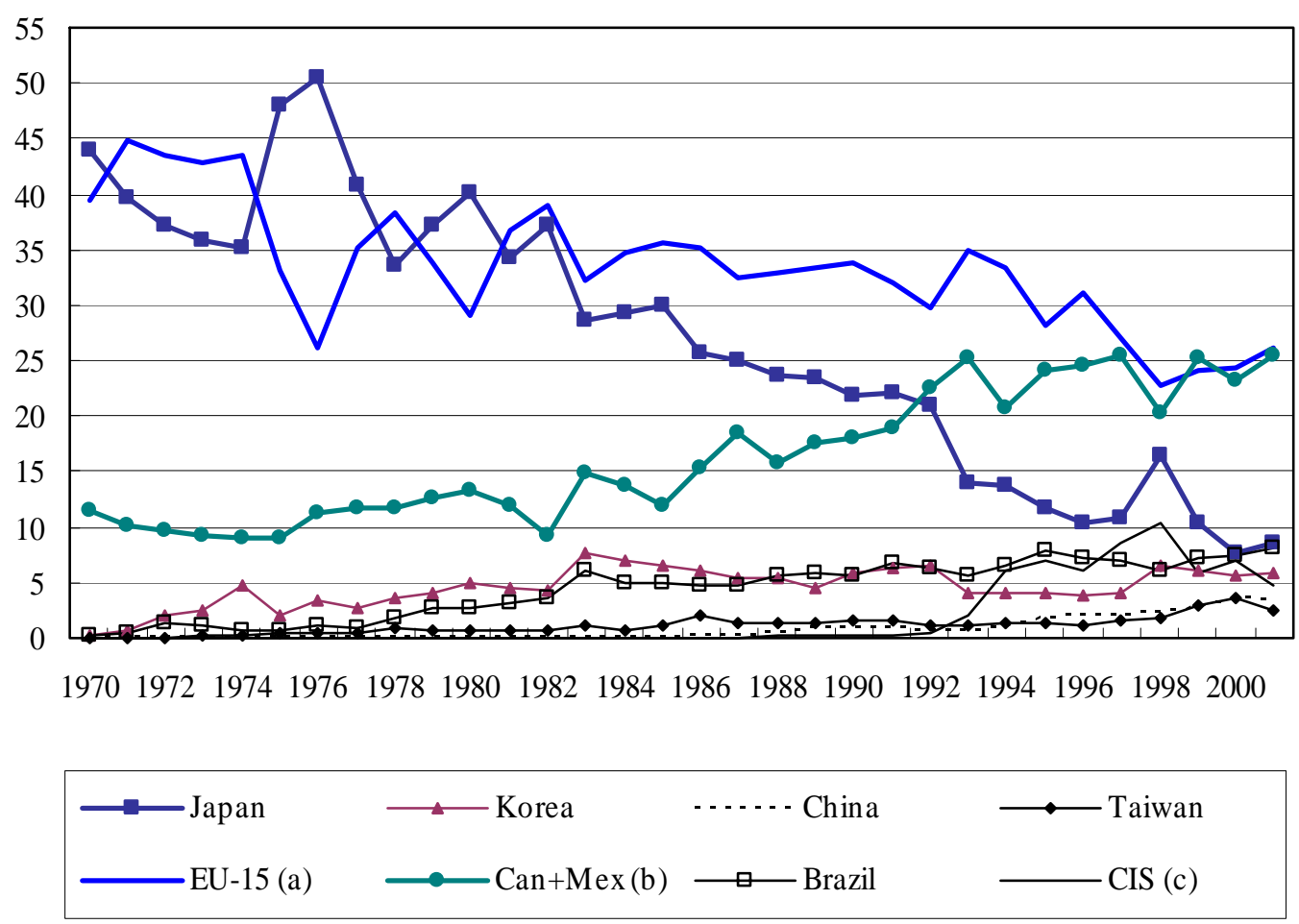

Notes:

(a) Austria, Belgium, Denmark, Finland, France, Germany, Great Britain, Greece, Ireland, Italy, Luxembourg, Netherlands, Portugal, Spain, and Sweden.

(b) Canada and Mexico.

(c) CIS countries are Armenia, Azerbaijan, Belarus, Estonia, Georgia, Kazakhstan, Kyrgyz Republic, Latvia, Lithuania, Moldova, Russia, Tajikistan, Turkmenistan, Ukraine, and Uzbekistan.

Source: Organisation for Economic Cooperation and Development (various years).

${ }^{5}$ Crandall (1981, p. 114) estimated that given the 15 percent increase in relative import prices of steel in 1978-1979 the TPM could have reduced the share of U.S. imports in total steel consumption from 18 percent to 13 percent. 
Fifth, Taiwan started exporting steel to the United States in the mid-1970s after China Steel began production in 1974, and it accounted for 1-4 percent of U.S. imports during 1978-2001. Finally, U.S. imports from Japan and Korea surged in 1998 as these countries tried to shift large shares of their exports to the United States when demand in Asia tumbled. However, largely because of the dramatic increase in U.S. antidumping suits in late 1998, particularly against imports from Japan, U.S. imports from Japan and Korea declined rapidly in 1999 (James and Parsons, 2003). Over the 1980-2001 period, the shares of U.S. steel imports from Japan, Korea, China and Taiwan declined from 46 percent in 1980 to 30 percent in 1990 and 20 percent in 2001.

Given the shares of U.S. imports from Northeast Asian and European countries have declined over time, which countries have been able to increase the market shares in the United States? As Figure 1 clearly indicates, U.S. steel imports from Canada and Mexico have increased significantly since the mid-1980s. The NAFTA partners accounted for over 25 percent of U.S. import share in 2001, up sharply from 12 percent in 1985 . The share of imports from Brazil increased from 3 percent in 1980 to 8 percent in 2001, whereas the share of CIS countries (primarily Russia, Ukraine and Kazakhstan) rapidly increased from under 1 percent in 1992 to 10 percent in 1998, before falling considerably in the subsequent years. ${ }^{6}$ Overall, the clear trends of increasing shares of U.S. imports from the NAFTA partners and Brazil and decreasing shares of the imports from the Northeast Asian countries and the EU have been revealed.

\section{Overview of the Model}

The model used in this study is a dynamic global CGE model developed by van der Mensbrugghe (2001). In the base model, all sectors are assumed to be perfectly competitive and operate under constant returns to scale. However, we later relax these assumptions by specifying imperfect competition and increasing returns to scale in the steel industry. Production in each sector is modeled by a series of nested CES production functions, which are intended to represent the different substitution and complementarity relations across various inputs in each sector. The CES nests for production archetype in

\footnotetext{
${ }^{6}$ The sharp drop in U.S. imports from Russia in 1999 might be caused by a sharp increase in its antidumping petitions and Russia’s export restraint agreement with the United States.
} 
Figure 2: Production Nesting in the Manufacturing and Services Sectors

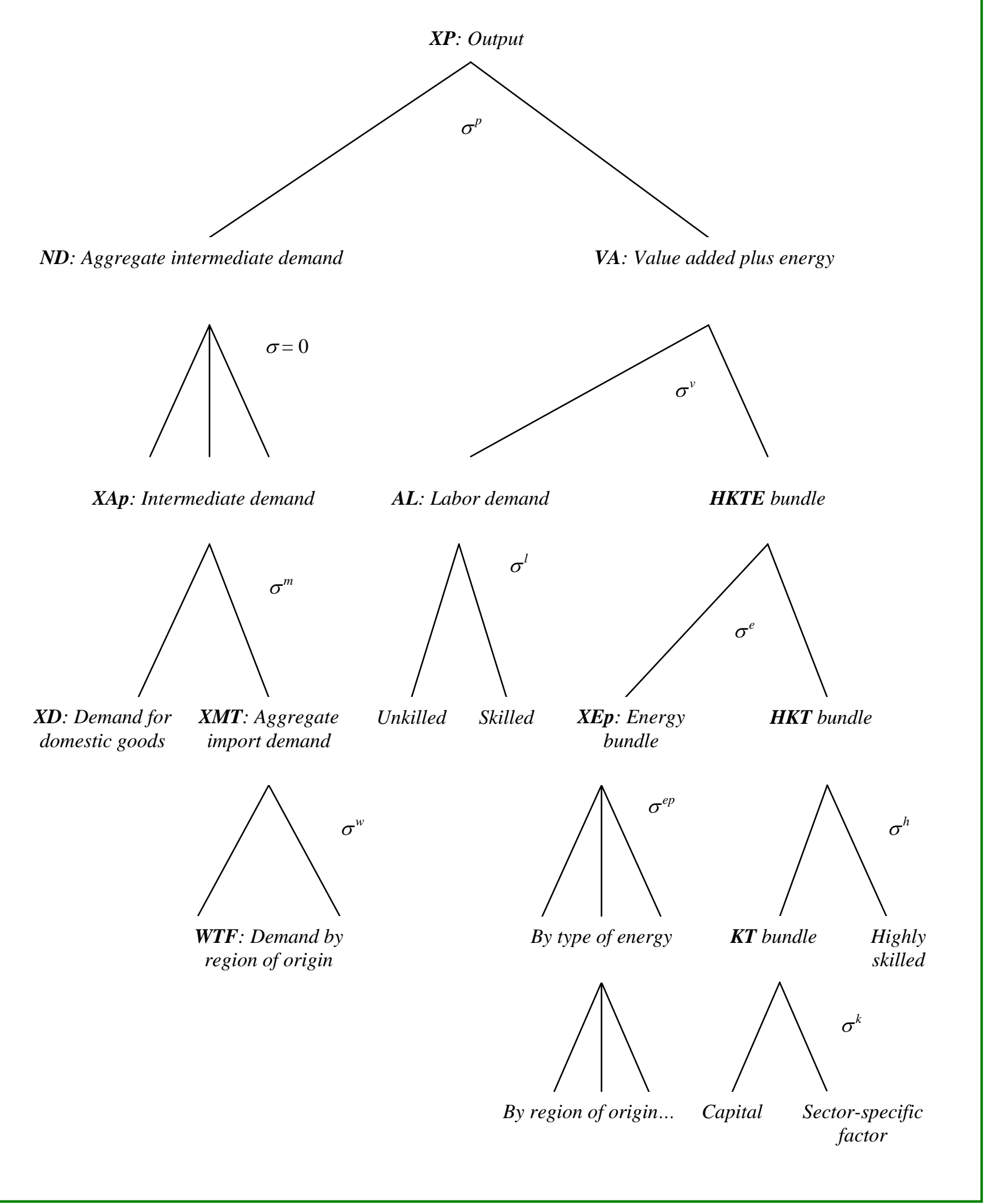


Figure 2 (continued)

Definition of variables and parameters:

$\begin{array}{ll}X P: & \text { Output (by vintage) } \\ N D: & \text { Demand for aggregate non-energy intermediate demand } \\ V A: & \text { Demand for labor, capital, energy, and sector-specific factor bundle } \\ X A p: & \text { Demand for (Armington) intermediate goods (excluding energy) } \\ X D: & \text { Demand for domestically produced intermediate goods } \\ X M T: & \text { Aggregate import demand for intermediate goods } \\ W T F: & \text { Demand for imported intermediate goods by region of origin } \\ A L: & \text { Demand for aggregate labor (excluding 'highly' skilled) } \\ H K T E: & \text { Demand for human and physical capital, energy, and sector-specific factor bundle } \\ X E p: & \text { Demand for aggregate energy bundle } \\ H K T: & \text { Demand for human capital, physical capital, and sector-specific factor bundle } \\ K T: & \text { Demand for physical capital and sector-specific factor bundle } \\ \sigma^{p}: & \text { Elasticity of substitution between } N D \text { and } V A \\ \sigma^{v}: & \text { Elasticity of substitution between } A L \text { and } H K T E \\ \sigma^{l}: & \text { Elasticity of substitution between unskilled and skilled labor } \\ \sigma^{e}: & \text { Elasticity of substitution between } X E p \text { and } H K T \\ \sigma^{e p}: & \text { Elasticity of substitution between different type of energy } \\ \sigma^{h}: & \text { Elasticity of substitution between } K T \text { and highly skilled labor } \\ \sigma^{k}: & \text { Elasticity of substitution between physical capital and sector-specific factor }\end{array}$

Note: The sector-specific factor includes land in agricultural sectors and the resource base in the coal, crude oil, natural gas, and mining sectors.

goods and services other than crops and livestock are depicted in Figure 2. At the top nest, production is formed by the combination of aggregate intermediate demand other than energy ( $N D)$ and value added plus energy (VA). The second nest consists of two nodes. The first node decomposes aggregate intermediate demand into sectoral demand for goods and services. The second node decomposes VA between demand for labor $(L)$ and demand for human capital, physical capital, energy and sector-specific factor composite (HKTE). The third and subsequent nodes are decomposed by a similar fashion, as illustrated in Figure 2.

Labor can have three different skill levels: unskilled, skilled and highly skilled. The first two are substitutable and combined in a CES aggregation function as a single labor bundle. Highly skilled labor is combined with capital to form a physical plus human capital bundle.

In each period, the supply of primary factors - capital, labor and land — is generally predetermined. The supply of land is assumed to be sensitive to the contemporaneous price of land, however. Land is assumed to be partially mobile across agricultural sectors. Thus rates of return are sector-specific, but sectoral land supply reacts to changes in 
relative rates of return. Some of the natural resource sectors also have a sector-specific factor whose contemporaneous supply is price sensitive. The model includes adjustment rigidities. An important feature is the distinction between old and new capital goods. In addition, capital is assumed to be partially mobile, reflecting differences in the marketability of capital goods across sectors. Labor and population growth are exogenous. Labor within each skill category is perfectly mobile across sectors.

All income generated by economic activity is assumed to be distributed to consumers. A single representative consumer (or household) allocates optimally his/her disposable income among the consumer goods and saving. The consumption/saving decision is static: saving is treated as a good and its amount is determined simultaneously with the demands for the other goods. The price of saving is set arbitrarily equal to the average price of consumer goods. Investment is driven by aggregate saving, or the sum of household, government and foreign savings. We assume that foreign saving is exogenous and that the ratio of government expenditures to GDP remains constant in each region over time.

Products are differentiated by region of origin and modeled as imperfect substitutes. On the import side, this is reflected by the implementation of the so-called Armington assumption, where a constant elasticity of substitution (CES) specification is used to incorporate imperfect substitution of imported goods with respect to domestically produced goods. A symmetric specification is used to model export supply, the latter being implemented with constant elasticity of transformation (CET) functions. Trade measures are fully bilateral and include both export and import taxes/subsidies. Trade and transport margins are also included; therefore world prices reflect the difference between FOB and CIF pricing.

The model is calibrated to a given baseline from 1997 to 2005. The per capita GDP growth rates are broadly consistent with the World Bank's forecast. Productivity is calibrated in the baseline to achieve the desired GDP trends. Several assumptions underline the calibration of productivity. Agricultural productivity is exogenous, userdetermined and varies across regions. Manufacturing productivity growth is assumed to be higher than services productivity growth. An economywide productivity factor is 
calibrated to achieve the given GDP target, and productivity growth is assumed to be labor-augmenting.

Table 1: Regional and Sectoral Aggregation

A. Regional Aggregation

\begin{tabular}{ll}
\hline Countries/Regions & Corresponding economies/regions in the GTAP database \\
\hline United States & United States \\
Japan & Japan \\
China & China, Hong Kong \\
Korea & Korea \\
Taiwan & Taiwan \\
ASEAN & Indonesia, Malaysia, Philippines, Singapore, Thailand, Vietnam \\
EU-15 & Austria, Belgium, Denmark, Finland, France, Germany, Great Britain, Greece, \\
& Ireland, Italy, Luxembourg, Netherlands, Portugal, Spain, Sweden \\
Canada and Mexico & Canada, Mexico \\
Other OECD & Australia, New Zealand, Switzerland, Rest of European Free Trade Area \\
Brazil & Brazil \\
Rest of Latin America & Central America and the Caribbean, Colombia, Peru, Venezuela, Rest of \\
& Andean Pact, Argentina, Chile, Uruguay, Rest of South America \\
Former Soviet Union & Armenia, Azerbaijan, Belarus, Estonia, Georgia, Kazakhstan, Kyrgyz Republic, \\
& Latvia, Lithuania, Moldova, Russia, Tajikistan, Turkmenistan, Ukraine, \\
& Uzbekistan \\
Cent. and E. Europe & Hungary, Poland, Rest of Central European Associates \\
Rest of the world & All the other economies/regions \\
\hline
\end{tabular}

B. Sectoral Aggregation

\begin{tabular}{ll}
\hline Sectors & Corresponding commodities/sectors in the GTAP database \\
\hline Agriculture & Agriculture, forestry, fishing \\
Energy & $\begin{array}{l}\text { Coal, oil, gas, petroleum and coal products, electricity, gas manufacture and } \\
\text { distribution }\end{array}$ \\
Minerals & Minerals \\
Processed food & Food products, beverages and tobacco products \\
Textiles and apparel & Textiles, wearing apparel, leather products \\
Chemical products & Chemical, plastic and rubber products \\
Iron and steel & Iron and steel \\
Nonferrous metals & Nonferrous metals \\
Metal products & Metal products \\
Machinery & Machinery \\
Electronic equip. & Electronic equipment \\
Motor vehicles & Motor vehicles and parts \\
Other transp. equip. & Other transport equipment \\
Other manufactures & Wood products, paper products, publishing, non-metallic mineral products, \\
& other manufactures \\
Construction & Construction \\
Transport services & Sea transport, air transport, transport n.e.s. \\
Other services & Trade, communication, financial services, other services \\
\hline
\end{tabular}

${ }^{\text {a }}$ In the GTAP database, Brunei, Cambodia, Laos, and Myanmar are aggregated into the rest of the world. Source: GTAP database, Version 5. 
Most of the data used in the model come from version 5 of the GTAP database, which provides 1997 data on input-output, value added, final demand, bilateral trade, tax and subsidy data for 66 regions and 57 sectors. ${ }^{7}$ For the purpose of the present study, the database is aggregated into 14 regions and 17 sectors as shown in Table 1 . The regional detail focuses on Northeast Asian steel producers as well as other major U.S. trading partners in steel. The sectoral detail focuses on steel and its downstream industries, such as metal products, general machinery, motor vehicles, other transport equipment and construction.

In the alternative specification, we model the steel industry to be imperfectly competitive by introducing a price markup over average cost. Increasing returns are calibrated to a cost disadvantage ratio given by

$$
C D R=\frac{A C-M C}{A C}=\frac{F C}{T C}
$$

where $A C, M C, F C$ and $T C$ are average, marginal, fixed and total costs, respectively. For illustrative purpose, we set both the price markup and cost disadvantage ratio to be 5 percent.

Two caveats should be borne in mind when we evaluate the effects of U.S. steel protection in the next section. First, as noted above, we later relax the assumptions of perfect competition and constant returns to scale for the steel industry, but imperfect competition is based on a simple specification where the price markup is exogenous. Although it is more realistic to assume that there are strategic interactions among the firms, it is extremely difficult to model them in a general equilibrium framework. Second, the model assumes full utilization of capital, which is probably not a reasonable assumption. There appears to be significant overcapacity of steel production in many countries. ${ }^{8}$ When capital is fully utilized, an increase in output of steel raises the rental rate of capital,

\footnotetext{
7 See Dimaranan and McDougall (2002) for detailed descriptions of the GTAP database, version 5.

8 Hufbauer and Goodrich (2001) suggest that world steel overcapacity has often exceeded 20 percent of production during the past 30 years.
} 
thereby increasing the marginal cost of production in the steel industry. By contrast, when capital is considerably underutilized, an increase in output is unlikely to raise the rental rate of capital. In other words, the greater the extent of underutilization of capital, the smaller will be an increase in the marginal cost (or the larger will be a reduction in the marginal cost under increasing returns to scale) resulting from an expansion of output. Thus, the costs of protection are likely to become lower in countries where steel output increases, whereas they are likely to become higher in countries where steel output contracts.

\section{Policy Scenario}

Table 2 summarizes U.S. safeguard measures for 11 categories of steel products. The initial decision was to impose TRQs on slabs and higher duties on the other 10 product categories for a period of three years starting in March 2002. Then the quota limit on slabs would be increased and the tariff rates on the other product categories would be reduced progressively each year. For example, tariffs of 30 percent in 2002, 24 percent in 2003, and 18 percent in 2004 were to be imposed on certain finished flat products (plate,

Table 2: U.S. Safeguard Measures by Product Category

\begin{tabular}{|c|c|c|c|}
\hline & \multirow[t]{2}{*}{ Product category } & \multicolumn{2}{|c|}{ Measures } \\
\hline & & First year & Second year \\
\hline 1 & Slab & $\begin{array}{l}5.4 \text { million short tons with } \\
\text { over-quota tariff of } 30 \%\end{array}$ & $\begin{array}{l}5.9 \text { million short tons with } \\
\text { over-quota tariff of } 24 \%\end{array}$ \\
\hline $\begin{array}{l}3 \\
4 \\
\end{array}$ & $\begin{array}{l}\text { Finished flat products (plate, hot- } \\
\text { rolled sheets, cold-rolled sheets, } \\
\text { coated sheets) } \\
\text { Hot-rolled bar } \\
\text { Cold-finished bar }\end{array}$ & $30 \%$ tariff & $24 \%$ tariff \\
\hline $\begin{array}{l}5 \\
6\end{array}$ & $\begin{array}{l}\text { Rebar } \\
\text { Certain welded tubular products }\end{array}$ & $15 \%$ tariff & $12 \%$ tariff \\
\hline 7 & $\begin{array}{l}\text { Carbon and alloy fittings and } \\
\text { flanges }\end{array}$ & $13 \%$ tariff & $10 \%$ tariff \\
\hline $\begin{array}{l}8 \\
9 \\
\end{array}$ & $\begin{array}{l}\text { Stainless steel bar } \\
\text { Stainless steel rod } \\
\end{array}$ & $15 \%$ tariff & $12 \%$ tariff \\
\hline 10 & Stainless steel wire & $8 \%$ tariff & $7 \%$ tariff \\
\hline 11 & Tin mill products & $30 \%$ tariff & $24 \%$ tariff \\
\hline
\end{tabular}

Source: U.S. Trade Representative (2002).

Note: 1 short ton equals 0.90718 metric tons. 
hot-rolled sheets, cold-rolled sheets and coated sheets), hot-rolled bar, cold-finished bar and tin mill products. ${ }^{9}$ However, because the safeguards were terminated in December 2003, the measures for the first two years are listed in Table 2.

In order to assess the consequences of the safeguard measures, it is necessary to compute their tariff equivalents on U.S. imports of iron and steel [Standard International Trade Classification (SITC) sector 67] because the GTAP database does not provide data on more disaggregated steel products. We compute an increase in the tariff rate on steel imports from region $r$ as follows:

$$
\Delta t_{r, t}=\sum_{i} \theta_{r, i} \Delta t_{i, t}
$$

where $\Delta t_{r, t}$ is the average increase in the U.S. tariff rate on imports of iron and steel from region $r$ in year $t, \theta_{r, i}$ is the share of $r$ 's steel product category $i$ in total U.S. steel imports from region $r$ in 2000, and $\Delta t_{i, t}$ is the increase in the tariff rate on product $i$ in year $t$.

Table 3: Increases in the U.S. Tariff Rates on Iron and Steel resulting from the Safeguard Measures (percent)

\begin{tabular}{lrc}
\hline Exporting region & 2002 & 2003 \\
\hline Japan & 7.5 & 6.0 \\
China & 5.2 & 4.2 \\
Korea & 10.3 & 8.3 \\
Taiwan & 9.3 & 7.5 \\
ASEAN & 1.2 & 1.0 \\
EU-15 & 8.3 & 6.7 \\
Canada and Mexico & 0.0 & 0.0 \\
Other OECD & 6.3 & 5.0 \\
Brazil & 2.6 & 2.1 \\
Rest of Latin America & 0.0 & 0.0 \\
Former Soviet Union & 5.9 & 4.7 \\
Cent. and E. Europe & 0.0 & 0.0 \\
Rest of world & 0.0 & 0.0 \\
\hline
\end{tabular}

Sources: U.S. Trade Representative (2002), Organisation for Economic Cooperation and Development (various years), and the authors' calculations.

${ }^{9}$ Over-quota shipments on slabs were imposed the same tariff rates as these product categories. See U.S. Trade Representative (2002). 
Estimates of increases in the U.S. tariff rates on iron and steel (SITC 67) resulting from its safeguard measures are provided in Table 3. For slabs we assumed that tariff equivalents of TRQs were 2 percent in the first year and 1.5 percent in the second year. It is worth noting that most developing and transitional countries were on the exclusion list. However, China, Korea, Taiwan and Malaysia were included in the safeguard action. For certain products, some developing and transitional countries were included: Brazil for slabs and flat products; India, Thailand and Romania for carbon flanges; Moldova, Turkey and Venezuela for rebar; and Thailand for welded pipe.

\section{Quantitative Assessments of the U.S. Safeguards}

In sections 5.1-5.3 below, the effects of the U.S. safeguards are evaluated using the base model with the assumptions of perfect competition and constant returns to scale in all industries. In section 5.4, we relax these assumptions for the steel industry and compare the results obtained under increasing returns with those obtained under constant returns.

\subsection{Effects on Economic Welfare and Real GDP}

Aggregate welfare gains and losses summarize the extent trade distortions are hindering growth prospects and the ability of economies to use the gains to help those whose income could potentially decline. We compare the U.S. safeguard scenario with the baseline situation for the years 2002-2005. Economic welfare is measured by Hicksian equivalent variation (EV), which represents the income consumers would be willing to forego to achieve post-policy well-being $\left(u^{p}\right)$ compared to baseline well-being $\left(u^{b}\right)$ at baseline prices $\left(p^{b}\right)$ :

$$
E V=E\left(p^{b}, u^{p}\right)-E\left(p^{b}, u^{b}\right)
$$

where $E$ represents the expenditure function to achieve utility level $u$ given a vector of prices $p$ (superscript $b$ represents baseline levels, and $p$ the post-reform levels). The model uses the extended linear expenditure system (ELES), which incorporates savings in the consumer's utility function (Lluch, 1973; Howe, 1975). The ELES expenditure function is easy to evaluate at each point in time. 
The welfare results are summarized in Table 4. For the years 2002 and 2003 when the safeguards were in place, U.S. welfare was estimated to be \$161-192 million higher than in the baseline where no safeguards were imposed. However, after the safeguard measures were terminated, U.S. welfare would become slightly lower than in the baseline (-\$34 million in 2004 and $-\$ 31$ million in 2005). Although not shown in the table, detailed results indicate that the changes in the terms of trade played the principal role in these welfare changes. A relatively large size of the U.S. steel market implies that a reduction in U.S. steel imports resulting from the safeguard duties would lower the world price of steel. As a result, the terms of trade for the United States and other net importers of steel improved while those for net exporters of steel deteriorated during the time when the safeguards were in place. In other words, the burden of the new U.S. tariffs was partially born by foreign producers. ${ }^{10}$

Table 4: Effects of the U.S. Safeguards on Economic Welfare (Deviations in equivalent variations from the baseline in respective years)

\begin{tabular}{lrrrrr}
\hline & \multicolumn{3}{c}{ Absolute changes (US\$ million in 1997 prices) } & \multirow{2}{*}{ Percent changes } \\
\cline { 2 - 4 } & 2002 & 2003 & 2004 & 2005 & in 2003 \\
\hline United States & 192.2 & 160.8 & -33.7 & -30.5 & 0.0018 \\
Japan & -88.8 & -76.8 & -7.0 & -6.2 & -0.0022 \\
China & 7.7 & 5.9 & 0.0 & 0.1 & 0.0005 \\
Korea & -59.7 & -53.7 & -5.0 & -4.6 & -0.0123 \\
Taiwan & -13.3 & -13.0 & -2.8 & -2.5 & -0.0042 \\
ASEAN & 2.0 & 1.6 & 0.4 & 0.3 & 0.0003 \\
EU-15 & -240.4 & -214.4 & -16.1 & -14.6 & -0.0032 \\
Canada and Mexico & 76.6 & 64.0 & 3.6 & 4.6 & 0.0068 \\
Other OECD & -16.9 & -14.5 & -1.0 & -1.1 & -0.0019 \\
Brazil & -4.4 & -3.9 & -0.6 & -0.6 & -0.0006 \\
Rest of Latin America & 3.1 & 2.2 & -0.5 & -0.7 & 0.0003 \\
Former Soviet Union & -58.4 & -48.7 & -1.1 & -1.3 & -0.0071 \\
Cent. and E. Europe & 16.1 & 13.3 & 0.0 & 0.0 & 0.0050 \\
Rest of world & 11.4 & 9.1 & 0.2 & -0.2 & 0.0006 \\
World total & -172.7 & -168.0 & -63.5 & -57.4 & -0.0006 \\
\hline
\end{tabular}

Source: Simulation experiments.

10 In his theoretical investigation, Johnson (1954) suggests a positive correlation between country size and the optimal tariff rate. 
As expected, most of the non-exempt countries incurred welfare losses. According to our results, the EU was the biggest loser in absolute terms with a reduction in its EV by \$214-240 million in 2002-2003, followed by Japan (\$77-89 million), Korea (\$54-60 million) and the former Soviet Union (\$49-58 million). In percentage terms, Korea incurred the greatest loss of 0.012 percent while Japan and Taiwan's welfare fell by $0.003-$ 0.004 percent compared with the baseline values in 2003. China did not suffer any welfare losses because its exports to the United States were quite small and it has been a net importer of steel.

In contrast to most of the non-exempt countries, economic welfare of the exempt countries increased during the U.S. impositions of safeguard measures on steel imports from the non-exempt countries. In particular, Canada and Mexico experienced increases in their EV of \$64-77 million in 2002-2003. This resulted from increases in their steel exports to the United States, thereby stimulating overall demand, as well as from an improvement in their terms of trade.

Table 5: Effects of the U.S. Safeguards on Real GDP

(Deviations from the baseline in respective years)

\begin{tabular}{|c|c|c|c|c|c|}
\hline & \multicolumn{4}{|c|}{ Absolute changes (US\$ million in 1997 prices) } & \multirow{2}{*}{$\begin{array}{r}\text { Percent changes } \\
\text { in } 2003\end{array}$} \\
\hline & 2002 & 2003 & 2004 & 2005 & \\
\hline United States & -118.1 & -117.0 & -37.0 & -35.6 & -0.0012 \\
\hline Japan & -33.0 & -28.2 & -6.6 & -6.4 & -0.0006 \\
\hline China & 2.3 & 2.5 & 1.1 & 1.0 & 0.0002 \\
\hline Korea & -13.2 & -13.8 & -7.0 & -6.8 & -0.0024 \\
\hline Taiwan & -2.4 & -3.4 & -3.4 & -3.2 & -0.0009 \\
\hline ASEAN & 4.2 & 4.0 & 0.6 & 0.5 & 0.0005 \\
\hline EU-15 & -52.3 & -50.9 & -17.6 & -16.9 & -0.0006 \\
\hline Canada and Mexico & 14.9 & 13.5 & 7.1 & 7.8 & 0.0011 \\
\hline Other OECD & -1.8 & -2.4 & -1.7 & -1.7 & -0.0002 \\
\hline Brazil & -1.5 & -1.6 & -0.8 & -0.8 & -0.0002 \\
\hline Rest of Latin America & -5.8 & -4.9 & -1.0 & -1.1 & -0.0006 \\
\hline Former Soviet Union & -7.2 & -7.8 & -1.9 & -2.1 & -0.0009 \\
\hline Cent. and E. Europe & 3.3 & 3.1 & 0.2 & 0.2 & 0.0009 \\
\hline Rest of world & 5.6 & 5.3 & -0.3 & -0.3 & 0.0002 \\
\hline World total & -205.0 & -201.7 & -68.3 & -65.5 & -0.0006 \\
\hline
\end{tabular}

Source: Simulation experiments.

Table 5 summarizes the impact of the safeguard measures on real GDP. Most notably, real GDP of the United States was estimated to be $\$ 117-118$ million lower in 
2002-2003 than in the baseline. This suggests that an increase in output of steel was more than offset by reductions in output of other goods and services in the United States. In percentage terms, the reduction in U.S. real GDP in 2003 was only 0.001 percent. For Japan, Korea and Taiwan, reductions in their real GDPs were smaller than the reductions in their EVs, as were for the EU, other OECD countries, Brazil and the former Soviet Union. In contrast, gains in real GDPs for Canada and Mexico, Central and Eastern Europe and the rest of the world were smaller than the gains in their EVs.

Overall, the effects of U.S. steel protection on economic welfare and real GDP were estimated to be extremely small. This might be partly caused by the fact that the volume of imports affected by the U.S. protection is quite small relative to the world trade, but it also highlights how small the steel industry is in economic terms. The results might also explain why there are relatively few complaints about the costs of protectionism in the steel industry.

\subsection{Effects on Trade Flows}

Table 6 presents trade flow adjustments in steel resulting from the U.S. imposition of safeguards. Figures are given in percent deviations from the baseline scenario for the year 2003. To what extent Northeast Asian and other non-exempt countries' steel exports to the United States were reduced? Would steel exports of the NAFTA partners and other countries on the exclusion list increase? Would major Northeast Asian steel exporters, such as Japan and Korea, increase their exports to the EU and East Asian markets to compensate for the reductions in their market shares in the United States? Answers to these questions are of particular interests to policy makers.

The percentage changes in U.S. steel imports by trading partner are highly correlated with the changes in the U.S. tariff rates on steel imports summarized in Table 3. The tariff equivalents of the U.S. safeguard measures were estimated to be highest in Korea, followed by Taiwan, the EU, Japan, other OECD, the former Soviet Union and China. The projected percent reductions in U.S. imports relative to the baseline in 2003 were largest (in absolute terms) for Korea (-25\%), followed by Taiwan $(-22 \%)$, the EU 
Table 6: Changes in Trade Flows in Steel resulting from the U.S. Safeguards (Percent deviations from the baseline in 2003)

\begin{tabular}{|c|c|c|c|c|c|c|c|c|c|c|}
\hline Exporting region & \multicolumn{10}{|c|}{ Importing region } \\
\hline United States & & -0.68 & -0.55 & -0.95 & -0.68 & -0.82 & 0.42 & -0.63 & -0.50 & -0.05 \\
\hline Japan & -16.56 & & -0.02 & -0.42 & -0.15 & -0.23 & 0.96 & -0.09 & 0.04 & -1.36 \\
\hline China (incl. HK) & -9.32 & -0.16 & -0.03 & -0.43 & -0.16 & -0.24 & 0.95 & -0.10 & 0.03 & -0.21 \\
\hline ASEAN & 5.42 & -0.14 & -0.01 & -0.41 & -0.14 & -0.29 & 0.96 & -0.08 & 0.05 & 0.12 \\
\hline EU-15 & -19.17 & -0.12 & 0.01 & -0.40 & -0.12 & -0.21 & 0.98 & -0.07 & 0.06 & -1.46 \\
\hline Canada and Mexico & 10.31 & -0.36 & -0.23 & -0.63 & -0.36 & -0.46 & 0.74 & -0.30 & -0.17 & 0.81 \\
\hline Other OECD & -12.79 & -0.14 & 0.00 & -0.41 & -0.13 & -0.21 & 0.97 & -0.08 & 0.05 & -1.15 \\
\hline Brazil & -0.14 & -0.18 & -0.05 & -0.45 & -0.18 & -0.07 & 0.93 & -0.12 & 0.01 & -0.01 \\
\hline Rest of Latin America & 10.52 & -0.17 & -0.04 & -0.44 & -0.17 & -0.24 & 0.93 & -0.11 & 0.01 & 1.14 \\
\hline
\end{tabular}

Source: Simulation experiments. 
(-19\%), Japan (-17\%), other OECD (-13\%), the former Soviet Union $(-11 \%)$ and China $(-9 \%)$, the exactly same order as the increases in the U.S. tariff rates on steel by trading partner.

The exclusions of the NAFTA partners and most developing and transitional countries imply that the price of imports from these countries relative to the price of imports from the non-exempt countries for U.S. steel consumers declined in 2002-2003. This led to increases in U.S. imports from Canada and Mexico, Latin America except Brazil, Central and Eastern Europe and the rest of the world by 10-11 percent, thus largely offsetting the fall in the total U.S. steel imports. ${ }^{11}$

According to our results, the U.S. safeguards did not induce the Northeast Asian countries to increase their exports to the EU or East Asian markets. Instead, their exports to Canada and Mexico increased slightly. Other than U.S. imports, adjustments in bilateral trade flows were extremely small. In the aggregate, the U.S. steel imports were estimated to decline by 5.9 percent (the last row of Table 6). The total steel exports of Japan, China, Korea and Taiwan fell by 1.4, 0.2, 1.9 and 0.7 percent, respectively, whereas those of Canada and Mexico, Latin American other than Brazil, Central and Eastern Europe and the rest of the world increased by $0.8,1.1,0.1$ and 0.6 percent, respectively (the last column of Table 6). Thus, although the safeguards affected U.S. bilateral trade with its trading partners significantly, their effect on global trade was limited.

\subsection{Effects on Sectoral Output and Average Cost}

The impact of the U.S. safeguard measures is expected to vary significantly across sectors. In particular, the industries that use steel intensively as an intermediate input are likely to be adversely affected by the safeguard duties. To what extent the steel-consuming industries in the United States and the Northeast Asian countries have been affected by the U.S. safeguards is of great concerns to policy makers in these countries.

11 Although the safeguard duties were imposed on imports of the designated steel products from Malaysia and those of carbon flanges from Thailand, tariff equivalents of the safeguard measures for the ASEAN countries were quite low. Thus, the relative price of imports from ASEAN also declined, and the resulting effect on U.S. steel imports from ASEAN was positive. 
Table 7 provides real output results for the year 2003 on steel and major steelconsuming industries - metal products, general machinery, motor vehicles, other transport equipment and construction-resulting from the temporary safeguards. Real output of steel in the United States was estimated to increase by 1.2 percent, whereas that of Canada and Mexico would increase by 2.1 percent, mainly driven by a sharp increase in the exports to the United States. The contraction in output of Northeast Asian producers was very small, ranging from -0.1 percent (China) to -0.8 percent (Korea).

Table 7: Changes in Output of Steel and Related Industries resulting from the U.S. Safeguards (Percent deviations from the baseline in 2003)

\begin{tabular}{lrrrrrr} 
& $\begin{array}{l}\text { Iron and } \\
\text { steel }\end{array}$ & $\begin{array}{l}\text { Metal } \\
\text { products }\end{array}$ & $\begin{array}{l}\text { General } \\
\text { Machinery }\end{array}$ & $\begin{array}{l}\text { Motor } \\
\text { vehicles }\end{array}$ & $\begin{array}{l}\text { Other trans. } \\
\text { equipment }\end{array}$ & $\begin{array}{l}\text { Construc- } \\
\text { tion }\end{array}$ \\
\hline United States & 1.258 & -0.126 & -0.142 & -0.117 & -0.102 & -0.007 \\
Japan & -0.280 & 0.027 & 0.080 & 0.077 & 0.061 & -0.005 \\
China & -0.053 & 0.035 & 0.021 & 0.000 & 0.018 & 0.000 \\
Korea & -0.763 & 0.078 & 0.139 & 0.067 & 0.157 & -0.024 \\
Taiwan & -0.340 & 0.161 & 0.087 & 0.034 & 0.070 & -0.018 \\
ASEAN & 0.072 & 0.073 & 0.063 & -0.008 & 0.056 & 0.000 \\
EU-15 & -0.658 & 0.036 & 0.087 & 0.035 & 0.106 & -0.006 \\
Canada and Mexico & 2.113 & 0.195 & -0.154 & -0.146 & -0.159 & 0.018 \\
Other OECD & -0.300 & 0.032 & 0.070 & 0.009 & 0.047 & -0.005 \\
Brazil & -0.003 & 0.012 & 0.019 & 0.011 & 0.016 & -0.002 \\
Rest of Latin America & 0.264 & 0.024 & 0.019 & -0.008 & -0.031 & -0.003 \\
Former Soviet Union & -0.704 & 0.021 & 0.059 & 0.032 & 0.089 & -0.006 \\
Cent. and E. Europe & 0.189 & -0.006 & -0.001 & -0.022 & 0.033 & 0.001 \\
Rest of world & 0.167 & 0.019 & 0.010 & -0.008 & 0.020 & 0.001 \\
World total & -0.027 & 0.001 & 0.006 & -0.010 & -0.006 & -0.005 \\
\hline
\end{tabular}

Source: Simulation experiments.

According to our results, the U.S. safeguards caused output contractions in the metal products, general machinery, motor vehicles, other transport equipment and construction sectors in the United States although the impact on these industries was extremely small. By contrast, it led to output expansions in the steel-consuming industries other than construction in Japan, China, Korea and Taiwan, even though the impact was again very small.

The effects on output of the steel-consuming industries were largely attributable to changes in their average costs. Table 8 presents the effects on average costs of steel and the downstream industries resulting from the U.S. safeguards. In the United States, the average costs of steel-consuming industries rose mainly because the price of steel 
increased. On the contrary, the average costs of the same industries in the non-exempt countries fell. Had the United States covered a much wider range of steel products or set considerably higher tariff rates, they might have lead to significant deteriorations in the international competitiveness of U.S. steel-consuming industries.

Table 8: Changes in Average Costs of Steel and Related Industries resulting from the U.S. Safeguards (Percent deviations from the baseline in 2003)

\begin{tabular}{lccccrr}
\hline & $\begin{array}{l}\text { Iron and } \\
\text { steel }\end{array}$ & $\begin{array}{l}\text { Metal } \\
\text { products }\end{array}$ & $\begin{array}{l}\text { General } \\
\text { Machinery }\end{array}$ & $\begin{array}{l}\text { Motor } \\
\text { vehicles }\end{array}$ & $\begin{array}{l}\text { Other trans. } \\
\text { equipment }\end{array}$ & $\begin{array}{l}\text { Construc- } \\
\text { tion }\end{array}$ \\
\hline United States & 0.137 & 0.121 & 0.105 & 0.052 & 0.038 & 0.030 \\
Japan & -0.003 & -0.008 & -0.015 & -0.008 & -0.006 & -0.008 \\
China & -0.001 & -0.001 & -0.002 & -0.001 & 0.000 & -0.001 \\
Korea & -0.013 & -0.020 & -0.045 & -0.021 & -0.020 & -0.024 \\
Taiwan & -0.006 & -0.007 & -0.011 & -0.006 & -0.001 & -0.007 \\
ASEAN & -0.005 & -0.003 & -0.005 & -0.001 & 0.000 & 0.000 \\
EU-15 & -0.010 & -0.010 & -0.019 & -0.010 & -0.006 & -0.011 \\
Canada and Mexico & 0.051 & 0.050 & 0.089 & 0.044 & 0.045 & 0.052 \\
Other OECD & -0.007 & -0.007 & -0.013 & -0.007 & -0.006 & -0.007 \\
Brazil & 0.003 & 0.003 & 0.007 & 0.003 & 0.004 & 0.003 \\
Rest of Latin America & 0.002 & 0.010 & 0.022 & 0.011 & 0.010 & 0.012 \\
Former Soviet Union & -0.028 & -0.029 & -0.058 & -0.028 & -0.030 & -0.030 \\
Cent. and E. Europe & -0.004 & -0.002 & -0.004 & -0.004 & -0.001 & -0.001 \\
Rest of world & 0.000 & 0.000 & 0.001 & 0.000 & 0.001 & 0.001 \\
World total & 0.009 & 0.007 & 0.004 & 0.002 & 0.002 & 0.001 \\
\hline
\end{tabular}

Source: Simulation experiments.

\subsection{Increasing Returns to Scale}

In any CGE models, simulation results are sensitive to the assumptions of the model. For example, previous studies (e.g., Harris, 1984; Brown and Stern, 1989; Francois and Roland-Holst, 1997) have shown that the gains from trade liberalization could be significantly larger when some of the sectors are characterized by imperfect competition and scale economies. Thus, the costs of the U.S. safeguards are likely to become higher if we relax the assumptions of perfect competition and constant returns to scale (CRS) and instead incorporate imperfect competition and increasing returns to scale (IRS) into the model.

Table 9 summarizes the results on economic welfare, real GDP, and U.S. steel imports under CRS and IRS in the steel industry. In the latter case, a 5 percent price markup over average cost and the cost disadvantage ratio (see equation 1) of 5 percent are 
introduced in the steel industry. In all the other industries, we still maintain the assumptions of perfect competition and CRS.

Table 9: Effects of the U.S. Safeguards under Constant Returns and Increasing Returns in the Steel Industry (Percent deviations from the baseline in 2003)

\begin{tabular}{|c|c|c|c|c|c|c|}
\hline \multirow[t]{2}{*}{ Region } & \multicolumn{2}{|c|}{$\begin{array}{c}\text { Economic welfare } \\
\text { (millions of } 1997 \text { US\$) }\end{array}$} & \multicolumn{2}{|c|}{$\begin{array}{c}\text { Real GDP } \\
\text { (millions of } 1997 \text { US\$) }\end{array}$} & \multicolumn{2}{|c|}{$\begin{array}{l}\text { U.S. imports of steel } \\
\text { (percent) }\end{array}$} \\
\hline & CRS & IRS & CRS & IRS & CRS & IRS \\
\hline United States & 160.8 & 220.2 & -117.0 & -56.6 & & \\
\hline Japan & -76.8 & -97.4 & -28.2 & -40.1 & -16.56 & -20.33 \\
\hline China & 5.9 & 1.6 & 2.5 & -0.7 & -9.32 & -11.49 \\
\hline Korea & -53.7 & -70.7 & -13.8 & -29.2 & -24.68 & -29.54 \\
\hline Taiwan & -13.0 & -17.4 & -3.4 & -6.9 & -21.69 & -26.07 \\
\hline ASEAN & 1.6 & 0.9 & 4.0 & 3.9 & 5.42 & 6.74 \\
\hline EU-15 & -214.4 & -306.7 & -50.9 & -136.9 & -19.17 & -23.11 \\
\hline Canada and Mexico & 64.0 & 111.5 & 13.5 & 52.5 & 10.31 & 12.69 \\
\hline Other OECD & -14.5 & -19.5 & -2.4 & -6.9 & -12.79 & -16.04 \\
\hline Brazil & -3.9 & -4.2 & -1.6 & -1.7 & -0.14 & -0.34 \\
\hline Rest of Latin America & 2.2 & 4.7 & -4.9 & -2.2 & 10.52 & 13.00 \\
\hline Former Soviet Union & -48.7 & -66.5 & -7.8 & -24.6 & -11.45 & -14.34 \\
\hline Cent. and E. Europe & 13.3 & 15.9 & 3.1 & 5.8 & 10.55 & 12.99 \\
\hline Rest of world & 9.1 & 15.6 & 5.3 & 12.7 & 10.53 & 12.97 \\
\hline World total & -168.0 & -211.8 & -201.7 & -231.2 & -5.86 & -6.98 \\
\hline
\end{tabular}

Note: CRS is the base model with perfect competition and constant returns to scale in all industries, whereas IRS introduces a 5 percent price markup over average cost and the cost disadvantage ratio of 5 percent in the steel industry.

Source: Simulation experiments.

As expected, the magnitudes of changes in economic welfare are generally larger under IRS than under CRS. An absolute change in steel output becomes greater when marginal cost declines with output. Thus, in countries where steel output expands (e.g., the United States, Canada and Mexico), larger increases in steel production have a positive effect on real GDP even though the change in real GDP is still negative in the United States because of output contractions in the steel-consuming sectors. Combined with the improvements in the terms of trade for these countries, the welfare gains would become larger for the United States and the countries that were exempted from the U.S. 
safeguards. ${ }^{12}$ By contrast, in countries where steel output contracts (e.g., Japan, Korea, Taiwan and the EU), greater reductions in steel output have a negative effect on real GDP. Combined with the deteriorations in the terms of trade for most of these countries, the welfare losses would become greater for most of the non-exempt countries. Because additional losses in economic welfare and real GDP are greater than additional gains in these variables under IRS, the world as a whole would incur greater welfare and real GDP losses from the U.S. safeguards when the steel industry is characterized by imperfect competition and IRS (the last row of Table 9).

Changes in U.S. imports of steel by trading partner are also magnified under IRS. For example, the reductions in imports from the Northeast Asian countries would increase from 9-25 percent under CRS to 11-30 percent under IRS. Similarly, U.S. imports from Canada and Mexico would increase from 10 percent to 13 percent.

\section{Concluding Remarks}

This paper has provided quantitative assessments of the temporary U.S. safeguards in 2002-2003 using a 14-region, 17-sector dynamic CGE model. The results suggest that the effects of the safeguards on economic welfare, real GDP, trade flows, and real output of steel and the downstream industries were very small. According to our results, the U.S. welfare marginally increased during the two years when the safeguards were in effect because of an improvement in its terms of trade. By contrast, U.S. real GDP was estimated to decline by $\$ 117-118$ million in 2002-2003 largely because an increase in the price of steel would reduce output of the steel-consuming industries. Japan, Korea and Taiwan incurred some welfare losses, but they were extremely small in percentage terms. China did not suffer any welfare losses as its exports to the United States were very small and it experienced a small improvement in the terms of trade. The reductions in real GDP were negligible for Japan, Korea and Taiwan as the expansions of the steel-consuming industries almost offset the contraction of the steel industry.

\footnotetext{
12 Using a partial equilibrium imperfect-competition model of the U.S. steel industry, Harris (1994) has shown that tighter quotas under VRAs could lead to an improvement in the U.S. welfare.
} 
U.S. steel imports from the Northeast Asian countries declined by 9-25 percent, and those from the EU, other OECD countries and the former Soviet Union fell by 11-19 percent. However, U.S. imports from the NAFTA partners and other countries on the exclusion list increased by 10-11 percent, largely offsetting the reductions in the total U.S. steel imports. Real output of steel in the United States was predicted to increase by 1.3 percent, whereas that of Northeast Asian producers contract by 0.1-0.8 percent. Canada and Mexico would realize a relatively large gain in real output, mainly driven by a sharp increase in their exports to the United States. The effects on output of the steel-consuming industries are negative in the United States and positive in the Northeast Asian countries, but they are extremely small. Under the alternative specification where the steel industry was characterized by imperfect competition and increasing returns to scale, the effects became larger, but still extremely small in percentage terms. These results suggest that the impact of the U.S. safeguards was minimal.

The magnitudes of our results are significantly smaller than those obtained by Francois and Baughman (2001), who estimated that U.S. GDP would fall by $\$ 500$ million to $\$ 1.4$ billion. This was because they evaluated the effects of the imposition of 9.2-20.7 percent tariffs on steel imports, which were of much higher tariff rates than used in our study. They also included only Canada and Mexico on the exclusion list although the great majority of developing countries were excluded from the U.S. safeguards.

In this paper, we attempted to estimate the impact of the temporary safeguards that were in effect in 2002-2003. Thus, no attempts were made to assess the effects of the protection of U.S. steel industry that existed prior to 2002, which were much more substantial and long-lasting. The effects of the safeguards were likely to be extremely small as we estimated, but the past U.S. protection policies might have had substantial effects on the bilateral trade flows in steel, as well as the efficiency and competitiveness of the steel and the steel-consuming industries in the United States and Northeast Asia. 


\section{References}

Brown, Drusilla K. and Robert M. Stern (1989), “U.S.-Canada Bilateral Tariff Elimination: The Role of Product Differentiation and Market Structure,” in F. C. Feenstra, ed., Trade Policies for International Competitiveness, Chicago: University of Chicago Press.

Crandall, Robert W. (1981), The U.S. Steel Industry in Recurrent Crisis, Washington, DC: The Brookings Institution.

Dimaranan, Betina V. and Robert A. McDougall, eds. (2002), Global Trade, Assistance, and Production: The GTAP 5 Data Base, West Lafayette: Center for Global Trade Analysis, Purdue University (http://www.gtap.agecon.purdue.edu/databases/v5/v5_ doco. asp).

Francois, Joseph F. and Laura Baughman (2001), "Costs to American Consuming Industries of Steel Quotas and Taxes,” Washington, DC: The Consuming Industries Trade Action Coalition Foundation, June (http://www.citac.trade.org/latest/citac_steel_ quotas_and_taxes_04_30_01.pdf).

Francois, Joseph F. and David Roland-Holst (1997), "Industry Structure and Conduct in an Applied General Equilibrium Context,” in J. F. Francois and K. A. Reinert, eds., Applied Methods for Trade Policy Analysis: A Handbook, Cambridge: Cambridge University Press.

Harris, Richard G. (1984), “Applied General Equilibrium Analysis of Small Open Economies with Scale Economies and Imperfect Competition,” American Economic Review, 74: 1017-1032.

Harris, Richard G. (1994), “Trade and Industrial Policy for a 'Declining’ Industry: The Case of the U.S. Steel Industry,” in P. R. Krugman and A. Smith, eds., Empirical Studies of Strategic Trade Policy, Chicago: University of Chicago Press.

Howe, Howard (1975), "Development of the Extended Linear Expenditure System from Simple Savings Assumptions,” European Economic Review, 6: 305-310.

Hufbauer, Gary Clyde and Ben Goodrich (2001), “Steel: Big Problems, Better Solutions,” Policy Briefs, Number PB01-9, Washington, DC: Institute of International Economics, July (http://www.iie.com/publications/pb/pb01-9.htm). 
Hufbauer, Gary Clyde and Ben Goodrich (2003), "Steel Policy: The Good, the Bad, and the Ugly,” Policy Briefs, Number PB03-1, Washington, DC: Institute of International Economics, January (http://www.iie.com/publications/pb/pb03-1.pdf).

James, William E. and Craig Parsons (2003), “International Trade in Steel Products: Evidence on 'Dumping' versus Competitive Behavior," Working Paper 2003-13, Kitakyushu: International Center for the Study of East Asian Development.

Johnson, Harry G. (1954), “Optimum Tariffs and Retaliation,” Review of Economic Studies, 21: 142-53.

Lluch, Constantino (1973), “The Extended Linear Expenditure System,” European Economic Review, 4: 21-32.

Organisation for Economic Cooperation and Development (various years), International Trade by Commodities Statistics ITCS, SITC/CTCI Rev. 2, 1997 (1961-1990 data), 2001 (1990-2000 data), and 2003 (1992-2002 data). CD-ROMs. Paris: OECD.

U.S. International Trade Commission (USITC) (2003), “Steel-Consuming Industries: Competitive Conditions with Respect to Steel Safeguard Measures,” Washington, DC: USITC (http://www.usitc.gov/pub3632/pub3632.htm).

U.S. Trade Representative (2002), “Section 201 Steel Remedy,” mimeograph, Washington, DC: U.S. Trade Representative (http://www.ustr.gov/sectors/industry/steel201/200203-05-201remedy.PDF).

van der Mensbrugghe, Dominique (2001), “LinKAGE Technical Reference Document,” Economic Policy and Prospects Group, The World Bank, October.

World Trade Organization (2003), United States - Definitive Safeguard Measures on Imports of Certain Steel Products: Final Reports of the Panel. Downloaded from the WTO website (http://docsonline.wto.org/DDFDocuments/t/WT/DS/248R-00.doc). 